\title{
Barley Yield and Nitrogen Derived by Plants from Mineral and Organic Fertilizers with Application of ${ }^{15} \mathrm{~N}$ Stable Isotope. Soliman, M. A. \\ Soil Department, Faculty of Agriculture, Damietta University, Egypt.
}

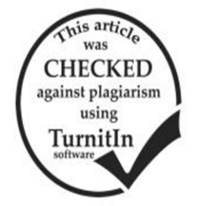

\section{ABSTRACT}

A field experiment was carried out with constructed drip irrigation system on sandy soil to recognize the most proper nitrogen fertilization strategy that could be more benefits for barley production taking into consideration the economical and environmental impacts. Barley crop was significantly positively affected by nitrogen fertilizer rates and organic compost. Grain yield (45\%) and shoot $(11 \%)$, root $(36 \%)$ dry weight were relatively increased with increasing $\mathrm{N}$ fertilizer rate. Plants fully fertilized with organic compost showed relative higher grain yield than those either received $100 \%$ or $50 \% \mathrm{~N}$-mineral fertilizer which accounted for $37 \%$. In this case, shoot and root dry matter yield were nearly closed to those of $50 \% \mathrm{~N}$-fertilizer, but to some extent lower than those of $100 \% \mathrm{~N}$-fertilized treatment. Plants treated with fully organic compost achieved $\mathrm{N}$ uptake by grains nearly closed to those obtained with high $\mathrm{N}$ fertilizer rate $\left(70 \mathrm{~kg} \mathrm{~N} \mathrm{fed}^{-1}\right)$. Combined treatment of organic plus mineral-N did not reflect significant differences than those of plants fertilized with half $\mathrm{N}$ fertilizer dose. Portion of nitrogen derived from fertilizer (Ndff) and absolute value reflected higher values and percentage at rate of $100 \%$ fertilizer than those induced by $50 \% \mathrm{~N}$ rate. Ndff by grain, shoot and root of combined treatment were nearly closed to those achieved by $50 \%$ mineral-N rate. More nitrogen was derived from organic compost and still higher in grain than shoot and root systems. Nitrogen added at half dose combined with organic compost was efficiently used by grain and root recording values nearly closed to those recorded with plants treated by half mineral-N rate.

Keywords: Barley, isotope dilution, mineral-N, ${ }^{15} \mathrm{~N}, \mathrm{~N}-$ rate, organic compost

\section{INTRODUCTION}

Historical background about the importance of barley written by Langridge (2018) indicated its interesting history. It is thought to be the first crop domesticated and developed as the staple food for the earliest farmers. While, production for the other major cereal crops, maize, rice and wheat, has continued to grow, barley production has stagnated over the past two decades. Today, barley is grown across the temperate regions of both the northern and southern hemispheres. Among cereals, barley came to the third position after wheat and maize (FAO 2011).

Proper nitrogen fertilization strategy is a limiting factor. Therefore, improvement of $\mathrm{N}$ efficiency is essential target in barley research. This target was found to be affected by many factors related to management, soil and plant itself (Andersson and Holm 2011). Enhancement of $\mathrm{N}$ fertilizer utilization in addition to those recovered from the soil may allow farmers to use moderate $\mathrm{N}$ quantities and in the same time achieved remarkable yield (Anbessa and Juskiw 2012, Bingham et al. 2012). Excess of nitrogen not utilized by plant and residue in soil may be exposed to losses via volatilization, denitrification and leaching (Cassman et al. 2002). Only 30-50\% of applied nitrogen fertilizer is taken up by crops (Dobermann 2005), hence the improvement in NUE is important to reduce input costs and the negative impact of excessive $\mathrm{N}$ on the environment (Snyder 2009, Anbessa and Juskiw 2012). Barley yields were about $68 \%$ higher at NPK fertilization and $55 \%$ at Nmineral + ST ( $5 \mathrm{t} \mathrm{ha}^{-1}$ spring barley straw) in comparison with unfertilized control. The highest nitrogen use efficiency of mineral fertilizers was recorded with farm yard manure application (Shejbalová et al. 2014).

Montemurro et al. (2006) showed that nitrogen fertilization at the start of cultivation plus organic $\mathrm{N}$ forms has a positive effect on yield component and induced good balance between productive parameters, $\mathrm{N}$ utilization efficiency indices and soil $\mathrm{N}$ deficit. Farmyard manure (FYM) plays an important role in supplying plant nutrients and enhancing soil productivity; soil organic carbon and available $\mathrm{P}$ and $\mathrm{K}$ contents increased with the application of FYM (Singh et al., 2000).
Kas et al. (2010) concluded similar positive effect of cereal straw and farmyard manure on barley yield. The combined application of chemical fertilizer and maize straw with a wide $\mathrm{C} / \mathrm{N}$ ratio is an important way of reducing the superfluous accumulation of $\mathrm{N}$ fertilizer $(\mathrm{Lu}$ et al., 2010).

Therefore, this work aims to recognize the proper management of both organic and mineral- $\mathrm{N}$ fertilization in field conditions for optimizing barley yield and enhancement of nitrogen use efficiency either applied in organic or mineral form.

\section{MATERIALS AND METHODS}

\section{Site description}

Winter barley seeds (Hordeum vulgare L.) Giza 127 were sown in the 2014/2015 cropping season in the research field of the Soil and Water Research Department, Nuclear Research Center, Atomic Energy Authority, Sharqeia Governorate, Egypt. The soil of the study site (located at latitudes30॰07'51" and 30॰14'57.33" N, and longitudes 31017'41.54" and 31021'11.19" E.) was classified as a sandy loam soil containing $79 \%$ sand, $15 \%$ silt and 6\% clay. The sandy loam soil had low initial organic matter $(0.035 \%)$, $\mathrm{pH}(7.8)$ and fairly low nitrogen content $(0.02-0.03 \%)$. Soil samples were analyzed according to Carter and Gregoreish (2008). This experiment was carried out to evaluate the effect of mineral fertilizer $\left({ }^{15} \mathrm{~N}\right.$-labelled ammonium sulfate $2 \%$ atom excess $)$ either added solely or in combinations with organic compost in different ratios. Organic compost was composed from Leuceana residues and cattle manure collected from our own farm located at Inshas area, mixed in $1: 1$ ratio $(\mathrm{W} / \mathrm{W})$ and composted in cement tanks for two months then samples of composted materials were taken for chemical analysis (Table 1). Analysis of composted materials was carried out according to Carter and Gregoreish (2008). The experimental treatments were arranged in Complete Randomized Block Design (CRBD) under field conditions. 
Table 1. Some chemical constituents of locally made compost.

\begin{tabular}{lc}
\hline Determinants & Compost \\
\hline $\mathrm{pH}(1: 5)$ & 7.00 \\
$\mathrm{EC} \mathrm{ds} \mathrm{m}{ }^{-1}$ & 3.60 \\
$\mathrm{C} / \mathrm{N} \mathrm{ratio}$ & 12.63 \\
$\mathrm{O} . \mathrm{M} \%$ & 60.34 \\
$\mathrm{~N} \%$ & 0.50 \\
$\mathrm{P} \%$ & 0.74 \\
$\mathrm{~K} \%$ & 0.808 \\
\hline $\mathrm{Microelements} \mu \mathrm{g} \mathrm{g}^{-1}$ & \\
$\mathrm{Fe}$ & 2859.2 \\
$\mathrm{Cu}$ & 205.92 \\
$\mathrm{Mn}$ & 184.52 \\
$\mathrm{Zn}$ & 166.88 \\
\hline
\end{tabular}

Basically, the recommended doses of phosphorus and potassium were applied to the experimental soil before cultivation. Phosphorus was applied at rate of $100 \mathrm{~kg} \mathrm{P}^{-} \mathrm{fed}^{-}$ ${ }^{1}$ (equal to $240 \mathrm{~kg} \mathrm{ha}^{-1}$ ) in the form of triple superphosphate, while potassium was added at rate of $50 \mathrm{~kg} \mathrm{~K}$ $\mathrm{fed}^{-1}$ (equal to $120 \mathrm{~kg} \mathrm{ha}^{-1}$ ) in the form potassium sulfate. Nitrogen was added in different rates either solely or in combinations with different rates of compost.

Fertilization treatments were: $100 \%$ recommended rate of labeled ammonium sulfate; $50 \%$ recommended rate; $100 \%$ organic compost; and $50 \%$ ammonium sulfate plus $50 \%$ Organic compost.

The experiment had a factorial arrangement with two levels of mineral $\mathrm{N}$ (70 and $35 \mathrm{~kg} \mathrm{fed}^{-1}$, referred to as N100, N50, respectively). Nitrogen levels N100 and N50 were applied after seedlings initiation either individually or plus organic compost, while organic compost was incorporated into the soil 30 days before cultivation. The two levels of $\mathrm{N}$ fertilizer and organic compost were applied in three replicates. There were a total of 12 plots, each with a gross area of $48 \mathrm{~m}^{2}$, under drip irrigation system.

Plant analyses were carried out according to Estefan et al, (2013), while ${ }^{15} \mathrm{~N} /{ }^{14} \mathrm{~N}$ ratio analysis was carried out using emission spectrometer model NOI-6PC following the information after IAEA, (2001). The following standard equations were used for estimation of nitrogen derived from fertilizer (Ndff), organic compost (Ndforg) and nitrogen use efficiency (\%NUE).

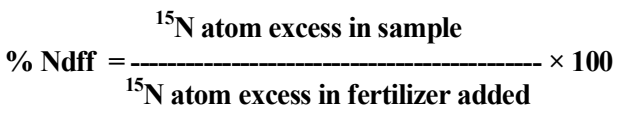

$\% \mathrm{NUE}=\mathrm{Ndff}$ yield/N fertilizer rate $\mathrm{x} 100$

$$
\% \mathrm{Ndforg}=\frac{{ }^{15} \mathrm{~N} \text { atom excess in untreated with organic }}{{ }^{15} \mathrm{~N} \text { atom excess in treated with organic }} \times 100
$$

Fertilizer-N\% remained in soil $=\frac{{ }^{15} \mathrm{~N} \% \text { a.e. in soil sample }}{{ }_{15} \mathrm{~N} \% \text { a.e. in added fertilizer }}$

All the obtained data were subjected to ANOVA analysis followed by Duncan's multiple range test (DMRT) for comparison between means using SAS software program (2002).

\section{RESULTS AND DISCUSSION}

\section{Growth and yield}

Barley plants fertilized with full $\mathrm{N}$ dose produced higher grain yield over those fertilized with the half dose (Table 2). Increments were relatively accounted for $45 \%$ over those received $50 \% \mathrm{~N}$-fertilizer rate. Shoot dry matter yield of fully fertilized plants recorded a relative increase by about $11 \%$ over those received half $\mathrm{N}$-fertilizer rate. Similar trend, but to somewhat higher extent (36\%), was observed in case of root dry matter yield. Both shoot and root systems noted lower dry matter yield than the grain yield. Plants fully fertilized with organic compost showed relative higher grain yield than those either received $100 \%$ or $50 \% \mathrm{~N}$-mineral fertilizer which accounted for $37 \%$. In this case, shoot and root dry matter yield were nearly closed to those of $50 \% \mathrm{~N}$-fertilizer, but to some extent lower than those of $100 \% \mathrm{~N}$-fertilized treatment. The best grain yield as affected by fertilization treatments was recorded with combination of mineral $\mathrm{N}$-fertilizer and organic compost at 50:50 rates. It was relatively increased by about $40 \%, 102 \%$ and $2 \%$ over fully mineral-N, half mineral-N and fully organic compost, respectively. It means that fully organic treatment and combined one were nearly closed to each other. From an economical view, we can recommend the full organic treatment. Due to findings of Berhanu et al., (2013), barley grain and straw yields were significantly increased with increasing $\mathrm{N}$ mineral fertilizer from 40 up to $120 \mathrm{~kg} \mathrm{ha}^{-1}$, and then tended to decrease. They recorded relative increase by about $68.4 \%$ in the grain yield (GY) of barley at $40 \mathrm{~kg} \mathrm{~N} \mathrm{ha}^{-1}$ and $89.4 \%$ at $80 \mathrm{~kg} \mathrm{~N} \mathrm{ha}^{-1}$. These findings are nearly closed to those we have.

Table 2. Effect of organic and mineral fertilization on growth and grain yield of barley crop (kg fed $^{-1}$ ).

\begin{tabular}{|c|c|c|c|c|}
\hline \multirow{2}{*}{ Treatments } & \multicolumn{4}{|c|}{ Dry weight kg fed $^{-1}$} \\
\hline & Grain & Shoot & Root & Shoot + Root \\
\hline \multicolumn{5}{|l|}{ Mineral-N \% } \\
\hline 100 & $1890 \mathrm{ab}$ & $639 \mathrm{bc}$ & $564 c$ & 1203 \\
\hline 50 & $1305 b$ & $577 \mathrm{bc}$ & $415 c$ & 992 \\
\hline Organic compost $100 \%$ & $2595 \mathrm{a}$ & $555 \mathrm{bc}$ & $465 c$ & 1020 \\
\hline \%Mineral+\%compost & & & & \\
\hline $50 \mathrm{M}+50 \mathrm{C}$ & $2649 a$ & $587 \mathrm{c}$ & $325 d$ & 912 \\
\hline
\end{tabular}
significantly different at $(P \leq 0.05)$

Also, they found that the application of organic fertilizer sources greatly enhanced the grain yield and yield components. Their results confirmed our results since the application of farm yard manure and residues achieved higher grain yield than those fertilized with mineral-N at different rates up to $120 \mathrm{~kg} \mathrm{~N}$ ha $^{-1}$.

Our findings proved that the integration between organic and mineral fertilizers could be more beneficial than the individual treatments. Similar results were also reported on barley (Agegnehu et al. 2016; Assefa 2015), wheat (Demelash et al. 2014; Getachew et al. 2014), tef (Getachew et al. 2014), maize (Mahmood et al. 2017; Wakene et al. 2005), Okra (Afe and Oluleye 2017) and tomato (Rajaie and Tavakoly 2016). This phenomenon 
may be attributed to positive changes of soil characteristics and nutrients availability (Tadesse et al., 2018).

Nitrogen uptake by barely grains (Table 3 ) was significantly increased with application of $100 \% \mathrm{~N}$ rate $(70$ $\left.\mathrm{kg} \mathrm{N} \mathrm{fed}{ }^{-1}\right)$ comparing to the half dose $\left(35 \mathrm{~kg} \mathrm{~N} \mathrm{fed}^{-1}\right)$. It was relatively increased by about $30 \%$ over those induced by half $\mathrm{N}$ dose. Similar trend, but to somewhat lower extent, was noticed with both shoot and root organs. Plants treated with fully organic compost achieved $\mathrm{N}$ uptake by grains nearly closed to those obtained with high $\mathrm{N}$ fertilizer rate $\left(70 \mathrm{~kg} \mathrm{~N} f e d^{-1}\right)$. Similar trend, but to low extent, was detected for shoot and root. Combined treatment of organic plus mineral-N did not reflect significant differences than those of plants fertilized with half $\mathrm{N}$ fertilizer dose. This holds true for all plant parts.

On line, Berhanu et al., (2013) recorded increments in nitrogen uptake with increasing rates of $\mathrm{N}$ fertilizer application, up to $120 \mathrm{~kg} \mathrm{~N} \mathrm{ha}^{-1}$ in the grain and up to 160 $\mathrm{kg} \mathrm{N} \mathrm{ha}{ }^{-1}$ in the straw. Residue additives found to be effective in increasing $\mathrm{N}$ uptake but the values were nearly closed or slightly lower than those of $\mathrm{N}$ fertilizer application. It could be that the crop residues as organic additives stimulated the soil microbial community, which in turn affected $\mathrm{N}$ mineralization and soil organic carbon (SOC) (Bending et al., 2002).

An explanation of $\mathrm{N}$ uptake enhancement by combined treatment $(50 \mathrm{M}+50 \mathrm{C})$ was reported by (Banik and Sharma, 2009) who indicated that organic and inorganic nutrient sources may enhanced the grain yield and biomass production. The use of organic sources nourished soil nutrients and built up soil organic matter (Berzsenyi et al., 2000; Kismányoky, 2009). In consistent, the complementary application of straw (organic source) and other residues was important for winter barley. The incorporation of straw into the soil can reduce dependence on mineral $\mathrm{N}$ fertilizer and return significant nutrients and SOC to the soil in the long term, therefore reducing fertilizer costs, lowering environmental risks and promoting sustainable production (Berhanu et al., 2013).

Soil enzymes and respiration activities in soil rhizosphere as well as nutrient uptake by barley plants may be enhanced by organic fertilization (Liang et al., 2005).

Table 3. Effect of organic and mineral fertilization on $\mathbf{N}$ uptake ( $\left.\mathrm{kg} \mathrm{fed}^{-1}\right)$ by grain, shoot and root of barley crop.

\begin{tabular}{|c|c|c|c|c|}
\hline \multirow{2}{*}{ Treatments } & \multicolumn{4}{|c|}{$\mathrm{N}$ uptake kg fed ${ }^{-1}$} \\
\hline & Grain & Shoot & Root & Shoot + Root \\
\hline \multicolumn{5}{|l|}{ Mineral-N \% } \\
\hline 100 & $32.9 \mathrm{a}$ & $30.2 \mathrm{ab}$ & $14.7 \mathrm{c}$ & 49.9 \\
\hline 50 & $25.3 \mathrm{~b}$ & $21.5 \mathrm{~b}$ & $8.6 \mathrm{~cd}$ & 30.1 \\
\hline Organic compost $100 \%$ & $33.4 \mathrm{a}$ & $29.6 \mathrm{ab}$ & $13.7 \mathrm{c}$ & 43.3 \\
\hline \multicolumn{5}{|l|}{ \%Mineral+ \%compost } \\
\hline $50 \mathrm{M}+50 \mathrm{C}$ & $25.4 \mathrm{~b}$ & $22.7 \mathrm{~b}$ & $9.3 \mathrm{~cd}$ & 49.0 \\
\hline
\end{tabular}

Nitrogen derived from chemical fertilizer and organic form was differentially affected by addition rates (Table 4). Portion Ndff and absolute value reflected higher values and percentage at rate of $100 \%$ fertilizer than those indicated with $50 \% \mathrm{~N}$ rate. This holds true with all plant parts but it was higher in grain than shoot and root, respectively.

Table 4. Effect of organic and mineral fertilization on $\mathbf{N}$ derived from fertilizer and organic compost $\left(\% \& \mathrm{~kg} \mathrm{fed}^{-1}\right)$ by grain, shoot and root of barley crop.

\begin{tabular}{|c|c|c|c|c|c|c|}
\hline \multirow{3}{*}{ Treatments } & \multicolumn{6}{|c|}{$\mathbf{N}$ derived from fertilizer $\mathbf{N d f f}$} \\
\hline & \multicolumn{2}{|c|}{ Grain } & \multicolumn{2}{|c|}{ Shoot } & \multicolumn{2}{|c|}{ Root } \\
\hline & $\%$ & kg & $\%$ & kg & $\%$ & kg \\
\hline \multicolumn{7}{|l|}{ Mineral-N \% } \\
\hline 100 & 83.5 & 27.5 & 51.0 & 18.0 & 23.5 & 3.5 \\
\hline 50 & 48.0 & 12.1 & 47.5 & 10.2 & 17.0 & 1.5 \\
\hline \multicolumn{7}{|l|}{ \%Mineral+ \%compost } \\
\hline \multirow[t]{3}{*}{$50 \mathrm{M}+50 \mathrm{C}$} & 47.0 & 11.9 & 40.0 & 9.1 & 17.0 & 1.6 \\
\hline & \multicolumn{6}{|c|}{$\mathrm{N}$ derived from organic compost Ndforg } \\
\hline & 53.0 & 13.5 & 60.0 & 13.6 & 83.0 & 7.7 \\
\hline
\end{tabular}

In case of combined treatment, Ndff by grain, shoot and root showed percentages and absolute values nearly closed to those indicated with $50 \%$ mineral-N rate. In this respect, more nitrogen was derived from organic compost and still higher in grain than shoot and root systems.

Shejbalová et al., (2014) found greater efficiency of nitrogen from organic fertilizers than mineral form. In the same direction, higher values of nitrogen efficiency (NUtE) achieved by organic fertilization (Angás et al. 2006). This may be attributed to lower available nitrogen.

Mineral nitrogen use efficiency (NUE) was slightly high in grain of plant treated with full recommended rate comparing to those treated with the half recommended rate (Table 5). Average of mineral fertilization treatments showed high NUE\% in grain followed by those of shoot while root reflected very poor NUE. Nitrogen added at half dose combined with organic compost was used by grain and root at NUE values nearly closed to those recorded with plants treated by half mineral-N rate. In contrast, those used by shoot of plant treated with $50 \%$ mineral-N was higher than those received half dose in combination with organic compost.

Table 5. Effect of organic and mineral fertilization on NUE (\%) used by grain, shoot and roots of barley crop.

\begin{tabular}{lccc}
\hline \multirow{2}{*}{ Treatments } & \multicolumn{3}{c}{ \%NUE } \\
\cline { 2 - 4 } & Grain & Shoot & Root \\
\hline Mineral-N \% & 39.3 & 25.7 & 5.0 \\
100 & 34.6 & 34.6 & 4.3 \\
\hline 0 & 34.0 & 26.0 & 4.6 \\
\hline \%Mineral+ \% compost & & \\
50M+50 C & &
\end{tabular}

Our results were nearly closed, especially in grain, to those of Shejbalová et al., (2014) who recorded higher nitrogen recovery $(60.3 \%)$ with combined treatment (mineral-N + straw ST) than those of only mineral fertilized plants (46.2\%). Similar trend was recorded earlier (Snyder 2009; Ladha et al. 2005).

Gadalla et al., (2008), concluded that the incorporation of leucaena residues and compost either individually or in combination have a positive role on enhancement of fertilizer-N utilization and consequently its recovery by barley plant which was altered. Farahani et $a l$. , (2011) explained that the steep slope of $\mathrm{N}$ increment in vermicompost treatments could be because of relatively 
higher mineralization rate at drought stress conditions which provide more available nitrogen to be absorbed by the plant, causing a more nitrogen concentration in the barley grain.

In addition, Tadesse et al., (2018) stated that integrated management of organic and mineral fertilizers achieved high yield of barley and enhanced grain quality and soil fertility. This is recommended for sustainable malting barley production. Their findings are quite different than results we have.

Nitrogen remained in soil and $\mathbf{N}$ fertilizer balance

Portion and absolute values of fertilizer- $\mathrm{N}$ remained in soil after harvest and fertilizer-N balance as affected by fertilization treatments are presented in Table (6). Grain was gained more nitrogen from fertilizer added at rate of $70 \mathrm{~kg} \mathrm{~N} \mathrm{fed}{ }^{-1}(100 \%)$, therefore, little quantities of fertilizer-N was left in the soil after harvest and also small percent was lost by any mechanism from the soil. Medium amounts of fertilizer-N were derived from fertilizer to grain and the rest was divided between those remained in soil and others lost where both were nearly closed to each other when plants treated with half $\mathrm{N}$ dose $(50 \%)$. More fertilizer-N was remained in the soil after harvest against small budget lost from the soil under combined treatment of mineral plus organic fertilizers.

Table 6. Effect of chemical fertilizer and organic amendments on fertilizer-N remained in soil and nitrogen fertilizer balance (\%) under barley plants.

\begin{tabular}{|c|c|c|c|c|c|c|c|c|c|c|c|c|}
\hline \multirow{4}{*}{ Treatments } & \multicolumn{12}{|c|}{ Fertilizer-N Balance (\%) } \\
\hline & \multicolumn{12}{|c|}{ Plant organs } \\
\hline & \multicolumn{4}{|c|}{ Grain } & \multicolumn{4}{|c|}{ Shoot } & \multicolumn{4}{|c|}{ Root } \\
\hline & NR\% & NR kg & NF\% & NL\% & NR\% & NR kg & NF\% & NL\% & NR\% & NR kg & NF\% & NL\% \\
\hline 100 & 8.5 & 5.9 & 83.5 & 8.0 & 8.5 & 5.9 & 51.0 & 40.5 & 8.5 & 5.9 & 23.5 & 68.0 \\
\hline 50 & 27.5 & 9.6 & 48.0 & 24.5 & 27.5 & 9.6 & 47.5 & 25.0 & 27.5 & 9.6 & 17.0 & 55.5 \\
\hline $50 \mathrm{M}+50 \mathrm{C}$ & 41.0 & 14.4 & 47.0 & 12.0 & 41.0 & 14.4 & 40.0 & 19.0 & 41.0 & 14.4 & 17.0 & 42.0 \\
\hline
\end{tabular}

$\mathrm{NR}, \mathrm{N}$ remained in soil; $\mathrm{NF}, \mathrm{N}$ gained from fertilizer; $\mathrm{NL}, \mathrm{N}$ fertilizer losses

In case of shoot, more fertilizer-N was lost from the soil when plants treated with $100 \%$ recommended rate. It decreases with decreasing fertilizer-N rate up to $50 \%$ of the recommended rate. In this respect, the lowest percent of $\mathrm{N}$ losses was detected with application of the combined treatment $(19 \%)$. Similar trend, but to somewhat higher extent, was detected with root system.

This result is lies between ranges of Smith and Gyles (1988) who found that nitrogen fertilizer remained in the soil, including that in roots, accounted for 56 to $35 \%$. Barley treated with different nitrogen rates under different water regimes reflected decreases in fertilizer-N remained in soil after harvest with low $\mathrm{N}$ rate comparing to the highest rates (Gaber et al., 2017). Nutrients are limiting factor via providing economically optimum nourishment to the crop. On the other hand, reduction of nutrient losses leads to support agricultural system sustainability through contributions to soil fertility or other components of soil quality (Mikkelsen et al., 2012). In this regard, Samak et al., (2016) found that nitrogen recovered by barley crop showed significant correlation with nitrogen added rates.

\section{CONCLUSION}

It is clear that compost application plus $35 \mathrm{~kg}$ $\mathrm{N} \mathrm{fed}^{-1}$ boosted yield, grain nitrogen concentration, comparable to individual treatments. It proves that barley grain yield more benefited from organic compost plus mineral-N than individual additions. Combined treatment of organic compost and mineral fertilizer achieved high amount of mineral-N remained in soil and this may be benefits for the succeeding crop in the rotation, in the same time decline the amount of nitrogen losses. The data of ${ }^{15} \mathrm{~N} /{ }^{14} \mathrm{~N}$ ratio analysis proved this result and gave us the chance to recommend the integrated nitrogen management of organic and mineral forms as a proper strategy under the given conditions.

\section{REFERENCES}

Afe A.I., and Oluleye, F. (2017). Responses of Okra (Abelmuschus esculenthus L. Moench) to combined organic and inorganic foliar fertilizers. Int J Recycl Org Waste Agric 6(3):189-193.

Agegnehu, G., Nelson, P.N., and Bird, M.I. (2016). Crop yield, plant nutrient uptake and soil physicochemical properties under organic soil amendments and nitrogen fertilization on Nitisols. Soil Tillage Res 160:1-13.

Anbessa, Y., and Juskiw, P. (2012). Review: Strategies to increase nitrogen use efficiency of spring barley. Canadian Journal of Plant Science, 92: 617-625.

Andersson, A., and Holm, L. (2011). Effects of mild temperature stress on grain quality and root and straw nitrogen concentration in malting barley cultivars. Journal of Agronomy and Crop Science, 197: 466-476.

Angás, P., Lampurlanés, J., and Cantero-Martínez, C. (2006). Tillage and $\mathrm{N}$ fertilization: Effects on $\mathrm{N}$ dynamics and barley yield under semiarid Mediterranean conditions. Soil and Tillage Research, 87: 59-71.

Assefa, W. (2015). Response of barley (Hordium vulgare L.) to integrated cattle manure and mineral fertilizer application in the vertisol areas of south Tigray, Ethiopia. J Plant Sci 3(2):71-76.

Banik, P., and Sharma, R. C. (2009). Effect of organic and inorganic sources of nutrients on the winter cropsrice cropping system in sub-humid tropics of India. Arch. Agron. Soil Sci., 55, 285-294. 
Bending, G. D., Turner, M. K., and Jones, J. E. (2002). Interactions between crop residue and soil organic matter quality and the functional diversity of soil microbial communities. Soil Biol. Biochem., 34, 1073-1082.

Berhanu, G.W., Kismányoky, T. and Sárdi, K. (2013). Effect of nitrogen fertilization and residue management on the productivity of winter barley (Hordeum vulgare 1.). Acta Agronomica Hungarica, 61(2), 101-111.

Berzsenyi, Z., Győrffy, B., and Lap, D. Q. (2000). Effect of crop rotation and fertilization on maize and wheat yields and yield stability in a long-term experiment. Eur. J. Agron., 13: 225-244.

Bingham, I.J., Karley, A.J., White, P.J., Thomas, W.T.B., and Russell, J.R. (2012). Analysis of improvements in nitrogen use efficiency associated with 75 years of spring barley breeding. European Journal of Agronomy, 42: 49-58.

Carter, M.R. and Gregorich, E.G. (2008). "Soil Sampling and Methods of Analysis". (2nd ed.), CRC Press Taylor \& Francis Group, 6000 Broken Sound Parkway NW, Suite 300 Boca Raton, FL, p. 1224.

Cassman, K.G., Dobermann, A., and Walters, D.T. (2002). Agroecosystems, nitrogen-use efficiency, and nitrogen management. Ambio: A Journal of the Human Environment, 31: 132-140.

Demelash, N., Bayu, W., Tesfaye, S., Zidat, F., and Sommer, R. (2014). Current and residual effects of compost and inorganic fertilizer on wheat and soil chemical properties. Nutr Cycling Agroecosyst 100(3):357-367.

Dobermann, A.R. (2005). Nitrogen use efficiency - State of the art. University of Nebraska, Lincoln.

Estefan, G., Sommer, R. and Ryan, J. (2013). "Methods of Soil, Plant and Water Analysis: A manual for the West Asia and North Africa regions". International Center for Agricultural Research in the Dry Areas (ICARDA), 3 Ed.

FAO (2011). FAOSTAT Database Agricultural Production. Available at http://apps.fao.org. Food and Agricultural Organization of the United Nations.

Farahani, S. M., Chaichi, M. R., Mazaheri, D., Tavakkol Afshari, R., and Savaghebi, Gh. (2011). Barley grain mineral analysis as affected by different fertilizing systems and by drought stress. J. Agr. Sci. Tech. 13: 315-326.

Gaber, El.I., Samak, R.R.M., Galal, Y.G.M. and Mohamed, M.A. (2017). Grain Yield and Nitrogen Uptake by Barley Subjected to Fertilization and Water Regimes Using ${ }^{15} \mathrm{~N}$ Stable Isotope. Arab J. Nucl. Sci. Appl., 50 (2), 55-66.

Gadalla, A.M., Abd El-Haleem, A. M. , Galal, Y. G. M. , Abdel Aziz, H. A. , and Sherien M. A. El-Degwy (2008). Barley benefits from organic nitrogen in residues applied to soil using ${ }^{15} \mathrm{~N}$ isotope dilution. In: Proceedings of 9th International Conference of Nuclear Sciences and Applications, Session Soil and Water Research p. 1-8.
Getachew, A., vanBeek, C., and Michael, I.B. (2014). Infuence of integrated soil fertility management in wheat and tef productivity and soil chemical properties in the highland tropical environment. J Soil Sci Plant Nutr 14:532-545.

IAEA, Vienna (2001). "Use of isotope and radiation methods in soil and water management and crop nutrition". Manual Training Course Series No.14. IAEA, Vienna.

Kas, M., Haberletes, J., and Matejkova, S. (2010). Crop productivity under increasing nitrogen rates and different organic fertilization system in a long-term IOSDV experiment in the Czech Republic. Arch. Agr. Soil Sci. J., 56: 451-461.

Kismányoky, T. (2009). Examination of NPK fertilization and organic manuring of winter wheat in long-term experiments and cereal crop rotation. Növénytermelés, 58, 59-73.

Ladha, J.K., Pathak, H., Krupnik, T.J., Six, J., and van Kessel, C. (2005). Efficiency of fertilizer nitrogen in cereal production: Retrospects and prospects. Advances in Agronomy, 87: 85-156.

Langridge, P. (2018). Economic and Academic Importance of Barley. In, N. Stein and G. J. Muehlbauer (eds.), The Barley Genome, Compendium of Plant Genomes, Springer International Publishing AG, part of Springer Nature, pp. 1-10.

Liang, Y., Si, J., Nikolic, M., Peng, Y., Chen, W., and Jiang, Y. (2005). Organic manure stimulates biological activity and barley growth in soil subject to secondary salinization. Soil Biol Biochem, 37, 1185-1195.

Lu, C., Ma, J., Chen, X., Zhang, X., Shi, Y., and Huang, B. (2010). Effect of nitrogen fertilizer and maize straw incorporation on $\mathrm{NH}_{4}{ }^{+}-{ }^{15} \mathrm{~N}$ and $\mathrm{NO}_{3}{ }^{-}-{ }^{15} \mathrm{~N}$ accumulation in black soil of north east China among three consecutive cropping cycles. J. Soil Sci. Plant Nutr., 10, 443-453.

Mahmood, F., Khan, I., Ashraf, U., Shahzad, T., Hussain, S., Shahid, M., Abid, M., and Ullah, S. (2017). Efects of organic and inorganic manures on maize and their residual impact on soil physico-chemical properties. J Soil Sci Plant Nutr 17(1):22-32.

Mikkelsen, R., Jensen, T., Snyder, L., Cliff, B., and Tom, W. (2012). Nutrient management planning and accountability. In Bruulsema, T.W., Fixen, P.E., Sulewski, G.D. (eds.), 4R Plant nutrition: A manual for improving the management of plant nutrition. Norcross, GA, USA: International Plant Nutrition Institute.

Montemurro, F., Ferri, D., and Convertini, G. (2006). Nitrogen indicators, uptake and utilization efficiency in a maize and barley rotation cropped at different levels and sources of $\mathrm{N}$ fertilization. Field Crops Res., 99, 114-124.

Rajaie, M., and Tavakoly, A.R. (2016). Effects of municipal waste compost and nitrogen fertilizer on growth and mineral composition of tomato. Int $\mathrm{J}$ Recycl Org Waste Agric 5(4):339-347. https://doi. org/10.1007/s40093-016-0144-4 
Soliman, M. A.

Samak, R.R.M., Gaber, El. I., Galal, Y.G.M. and Mohamed, M.A. (2016). Barley Nitrogen Acquisition as Affected by Water Regime, Fertilizer Rates and Application Mode Using ${ }^{15} \mathrm{~N}$ Stable Isotope. Int.J.Curr.Microbiol.App.Sci. 5(1): 116-135

SAS (2002). The SAS System for Windows. Release 9. 0. SAS Inst. Inc., Cary, NC.

Shejbalová, Š., Černý, J., Vašák, F. , Kulhánek, M., and Balík, J. (2014). Nitrogen efficiency of spring barley in long-term experiment. Plant Soil Environ, Vol. 60, No. 7: 291-296.

Singh, Y., Singh, B., Meelu, O. P., and Khind, C. S. (2000). Long-term effects of organic manuring and crop residues on the productivity and sustainability of rice-wheat cropping system in Northwest India. pp. 149-162. In: Abrol, I. P., Bronson, K. F., Duxbury, J. M., Gupta, R. K. (eds.), Long-term soil fertility experiments in rice-wheat cropping systems. rice wheat consortium for the IndoGangetic Plains. Rice-Wheat, Consortium Paper Series 6. New Delhi, India.
Smith C.J. and Gyles O.A. (1988). Fertilizer nitrogen balance on spring irrigated malting barley. Fertilizer Research 18:3-12.

Snyder, C.S. (2009). Nitrogen use efficiency: Global challenges, trends and the future. Nutrient use efficiency. In: Proceedings of the XVIII Latin American Congress of Soil Science, 16-20th November 2009, Costa Rica, 10-17.

Tadesse, K., Mekonnen, A., Admasu, A., Admasu, W., Habte, D., Tadesse, A. and Tilahun, B. (2018). Malting barley response to integrated organic and mineral nutrient sources in Nitisol. Int $\mathrm{J}$ Recycl Org Waste Agric 7:125-134.

Wakene, N., Heluf, G., and Friesen, D.K. (2005). Integrated use of farmyard manure and NP fertilizers for maize on farmers' fields. J Agr Rural Dev Tropic 106(2):131-141.

\footnotetext{
انتاجية الثعير والنيتروجين المستمد من الأسمدة المعدنية والعضوية مع تطبيق النظير المستقر - نيتروجين-15 ـ

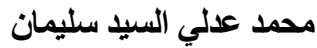
قسم الأراضي، كلية الزراعة، سلئ جامعة دمياط

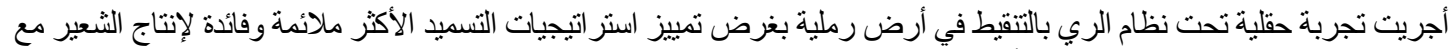

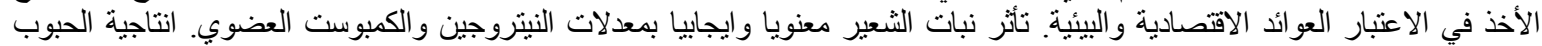

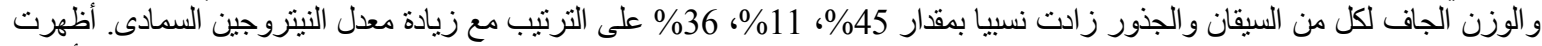

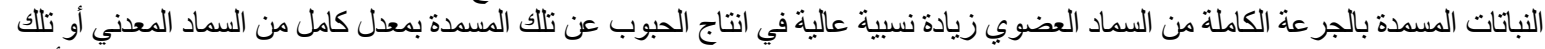

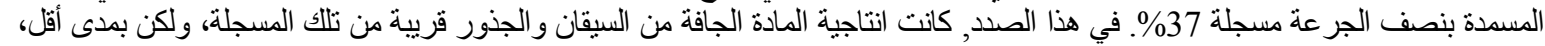

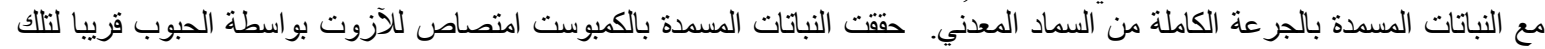

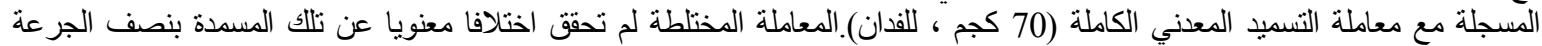

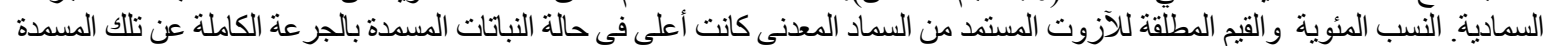

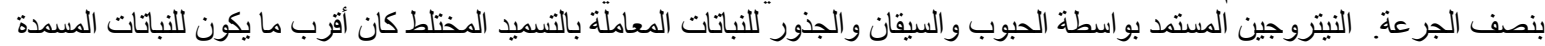
بنصف الجرعة السمادية. كثير من النيتروجين أستمد من الكمبوست العضوي وكان وكان أعلى في حالة الحبوب عن السيقان والجذور. النيتروجين

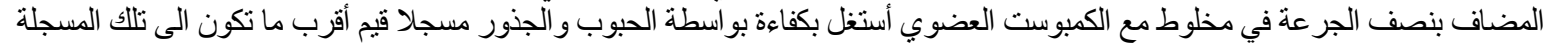
مع النباتات المسمدة بنصف الجرعة فئر مخدمة السمادية.
} 